\title{
ANALYSIS OF CHILDREN POETRY WRITING SKILLS ON CLASS V STUDENTS SDN 181 PEKANBARU
}

\author{
Ghea Febian Huda \\ Universitas Riau, Pekanbaru, Indonesia \\ gheafebianhuda31@gmail.com
}

\begin{abstract}
This study aims to determine the poetry writing skills of students in class V SDN 181 Pekanbaru based on aspects of theme, imagination, diction, and performance. Because of the lack of students 'poetry writing skills due to students' lack of skill in expressing ideas and thoughts. therefore by analyzing we can find out which aspects are not mastered by students. The study was conducted in class V odd semester of 2019 . The sample in this study was saturated sampling. The assessment instrument used was a poetry writing skills test using a poetry writing assessment descriptor. The dato obtained from poetry writing skills seen from 4 aspects, namely theme, imagination, diction and presentation, it can be concluded that the poetry writing skills of children who are categorized as highly skilled there are 5 (3.67\%), then 9 (6.57\%) skilled categories, and 103 (75.18\%) were categorized as quite skilled, while students who were categorized as less skilled were 20 (14.60\%) as a whole. Over all poetry writing skills class $V$ SND 181 Pekanbaru obtain the average value of 64 categorized enough.
\end{abstract}

Keywords: poetry writing skills

\section{ANALISIS KETERAMPILAN MENULIS PUISI ANAK PADA SISWA KELAS V SDN 181 PEKANBARU}

\begin{abstract}
ABSTRAK
Penelitian ini bertujuan untuk mengetahui keterampilan menulis puisi anak pada siswa kelas V SDN 181 Pekanbaru berdasarkan aspek tema, imajinasi, diksi, dan permajasan. Karena kurangnya keterampilan menulis puisi siswa disebabkan kurang terampilnya siswa dalam mengungkapkan ide gagasan dan pemikiran. Oleh karena itu dengan menganalisis kita dapat mengetahui aspek mana saja yang belum dikuasai oleh siswa. Penelitian dilakukan dikelas V semester ganjil tahun 2019. Sampel dalam penelitian ini adalah sampling jenuh. Instrument penilaian yang digunakan adalah tes keterampilan menulis puisi menggunakan descriptor penilaian menulis puisi. Data yang didapat dari keterampilan menulis puisi dilihat dari 4 aspek yaitu tema, imajinasi, diksi dan permajasan, dapat disimpulkan bahwa keterampilan menulis puisi anak yang berkategori sangat terampil ada 5 (3.67\%), kemudian 9 (6.57\%) berkategori terampil, dan 103 (75.18\%) berkategori cukup terampil, sedangkan siswa yang berkategori kurang terampil 20 (14.60\%) secara keseluruhan keterampilan menulis puisi anak pada siswa kelas V SDN 181 Pekanbaru memperoleh nilai rata-rata 64 berkategori cukup terampil.
\end{abstract}

Kata Kunci: keterampilan menulis puisi

\begin{tabular}{|c|c|c|}
\hline Submitted & Accepted & Published \\
\hline 09 Juli 2020 & 09 September 2020 & 26 September 2020 \\
\hline
\end{tabular}

\begin{tabular}{|l|c|c|c|}
\hline Citation & $:$ & $\begin{array}{c}\text { Huda, G.F. (2020). Analysis Of Children Poetry Writing Skills On Class V Students Sdn 181 Pekanbaru. Jurnal PAJAR } \\
\text { (Pendidikan dan Pengajaran), 4(5), 987-993. DOI : http://dx.doi.org/10.33578/pjr.v4i5.8102. }\end{array}$ \\
\hline
\end{tabular}

\section{PENDAHULUAN}

Menulis adalah keterampilan berbahasa yang sering digunakan untuk berkomunikasi, dapat dilakukan dengan tatap muka atau secara langsung dan juga secara tidak langsung (Tarigan, 2008). Menulis puisi merupakan suatu keterampilan menggunakan rangkaian bahasa dalam bentuk bahasa tulis untuk menyampaikan sebuah ide, gagasan ataupun pesan. Menulis puisi juga akan mendorong siswa untuk belajar bermain dengan kata-kata, menjelaskan pemikirannya pada suatu cara yang khas dan menyadari bahwa imajinasi yang ada pada dirinya dapat menjadi nyata bila di tuliskan dalam sebuah puisi. Puisi adalah salah satu ragam sastra. Puisi adalah ragam sastra yang diungkapkan dengan bahasa yang singkat padat dan indah.

Puisi adalah karangan yang terikat atau bisa dikatakan puisi itu terikat oleh peraturan yang 
ketat (Nurgiyantoro, 2016). Menurut Rumini dalam meningkatkan keterampilan dan kualitas siswa dalam pembelajaran bahasa dapat diperoleh dari menulis, ketika siswa menguasai keterampilan menulis maka siswa dapat menuangkan ide, gagasan, pemikiran ataupun perasaan (Kurniaman, 2018). Puisi adalah sebuah hasil dari penyaringan pengalaman yang ditangkap dari pikiran atau perasaan terhadap sesuatu. Didalam puisi anak kesederhanaan menjadi objek tersendiri karena terkadang keindahan puisi ada dalam kesederhanaan tersebut. Pada puisi anak intensitas keluasan makna belum seluas puisi dewasa karna daya jangkauan imajinasi anak dalam pemaknaan puisi masih terbatas. (Nurgiyantoro, 2016). Puisi anak juga memiliki karakteristik tersendiri yang identik dengan sastra anak yaitu mengungkapkan sesuatu berdasarkan apa yang ia lihat atau berdasarkan kaca mata anak.

Menulis puisi perlu dikenalkan kepada siswa sejak sekolah dasar sehingga siswa mempunyai kemampuan untuk mengapresiasi puisi dengan baik namun secara umum pembelajaran menulis puisi biasanya harus didasarkan dari sebuah tema, padahal menulis puisi dapat dikembangkan dari berbagai kejadian yang nyata yang dialami oleh siswa baik itu menyenangkan, mengharukan ataupun menyedihkan. Pembelajaran menulis puisi di sekolah dasar dilaksanakan hanya untuk memenuhi target kurikulum saja. Kebanyakan hal yang terjadi disekolah Kurangnya keterampilan menulis puisi siswa disebabkan kurang terampilnya siswa dalam mengungkapkan gagasan yang akan mereka tuliskan, oleh sebab itu analisis puisi mempunyai peranan penting. Dengan menganalisis keterampilan menulis puisi maka dapat diketahui dari aspek mana saja yang belum dikusasai oleh siswa, dengan begitu dapat memperbaiki pembelajaran menulis yang telah dilaksanakan sebelumnya, Menurut (Nurgiyantoro, 2010) menjelaskan bahwa penilaian dalam pembelajaran menulis puisi memperhatikan beberapa aspek yaitu tema, imajinasi, diksi, permajasan dan makna.

\section{METODE PENELITIAN}

Jenis penelitian yang digunakan dalam penilaian ini adalah penelitian deskriptif kuantitatif. Penelitian ini dilakukan pada siswa kelas V SDN 181 Pekanbaru yang berjumlah 137 siswa sample yang digunakan adalah sampling jenuh dimana semua anggota populasi dijadikan sample. Instrumen penilaian yang digunakan adalah tes keterampilan menulis puisi menggunakan deskriptor penilaian sesuai dengan indikator penilaian puisi yaitu aspek tema, aspek imajinasi, aspek diksi, dan aspek permajasan kemudian data yang diperoleh tersebut dianalisis berdasarkan hasil yang diperoleh dengan cara

1. Mengumpulkan hasil tes, yaitu membaca dan mengoreksi hasil puisi yang telah ditulis oleh siswa

2. Memberikan skor penilaian

3. Memindahkan skor tersebut kedalam tabel

4. Mencari nilai kemampuan menulis puisi dengan aspek mengkonversikan skor mentah menjadi nilai

Rumus : $\mathrm{N}=\frac{F}{S} \mathrm{X} 100 \quad$ (Nurgiyantoro B., 2010)

\section{Keterangan :}

$\mathrm{N}$ : nilai yang diperoleh

F: jumlah skor yang didapat

S: jumlah skor maksimal

5. Menentukan kategori kemampuan menulis puisi siswa

Tabel 1. Interval Tingkat Keterampilan Menulis Puisi

\begin{tabular}{ccc}
\hline Interval nilai & Nilai ukuran skala & Keterangan \\
\hline $86-100$ & $\mathrm{~A}$ & Sangat terampil \\
$76-85$ & $\mathrm{~B}$ & Terampil \\
$56-75$ & $\mathrm{C}$ & Cukup terampil \\
$10-55$ & $\mathrm{D}$ & Kurang terampil \\
\hline
\end{tabular}

Menurut Nurgiyantoro dalam (Lestari, 2014) 
6. Membuat tabel grafik yang berisi jumlah siswa dengan keterampilan menulis berdasarkan 4 aspek puisi berdasarkan kategori

7. Menganalisis puisi berdasarkan aspek yang ditentukan

8. Mengklasifikasikan kemampuan menulis puisi siswa dalam kategori menulis puisi siswa dalam pembahasan .

9. Menghitung nilai rata rata dengan mneggunakan rumus hitung sebagai berikut.

$\mathrm{Mi}=\frac{\sum x i}{n}$

(Alexander, 2013)

Keterangan :

$\mathrm{Mi}=$ rerata yang dicari

$\sum=$ jumlah nilai siswa

$\mathrm{N}=$ jumlah siswa ( sampel ).

10.Menentukan kategori keterampilan menulis puisi sisiwa berdasarkan kriteria.

11.Menarik kesimpulan dari hasil yang diperoleh dari keterampilan menulis puisi siswa

\section{HASIL DAN PEMBAHASAN}

\section{Deskripsi penelitian}

Penelitian ini dilakukan oleh peneliti dalam waktu dua minggu yang terdiri dari empat kelas yaitu VA,VB,VC,VD yang keseluruhannya berjumlah 137 siswa. Siswa diminta untuk menulis puisi anak, puisi anak pada dasarnya sama dengan puisi pada umumnya namun makna dari puisi tersebut lebih sederhana dan diungkap kan dengan apa adanya, tema yang digunakan dalam puisi anak adalah hal-hal yang berkaitan dengan kehidupan sehari-hari seperti orang tua, guru, lingkungan ataupun binatang peliharaan. Setelah data diolah dan hasil diketahui peneliti merekapnya dan menyimpulkan keterampilan menulis puisi berdasarkan empat aspek yaitu tema, imajinasi, diksi dan permajasan.

\section{Analisis keterampilan menulis puisi}

Keterampilan menulis puisi anak diperoleh berdasarkan aspek yaitu tema, imajinasi, diksi dan permajasan. Rata-rata keterampilan menulis puisi anak dapat dilihat dari jumlah keseluruhan aspek adalah sebagai berikut .

a. Indikator Tema

Aspek tema dalam kemampuan menulis puisi anak berarti kemampuan siswa terhadap isi,gagasan dalam puisi. Menurt salam dalam (Dibia, 2018) Tema adalah gagasan pokok yang dikemukakan penyair, dalam puisi anak banyak ditemukan tema keluarga, persahabatan, liburan, rumah, taman dan lain-lain.

Tabel 2. Rekapitulasi Keterampilan Menulis Puisi Anak Pada Aspek Tema

\begin{tabular}{cccc}
\hline Interval nilai & Jumlah siswa & \% & Kategori \\
\hline $86-100$ & 123 & $89.78 \%$ & Sangat Terampil \\
$76-85$ & 8 & $5.84 \%$ & Terampil \\
$56-75$ & 3 & $2.19 \%$ & Cukup Terampil \\
$10-55$ & 3 & $2.19 \%$ & Kurang Terampil \\
\hline Jumlah $\left(\sum\right)$ & $\mathbf{1 3 7}$ & $\mathbf{1 0 0 \%}$ & \\
\hline Jumlah Nilai & $\mathbf{1 3 . 1 2 5}$ & & \\
\cline { 1 - 3 } Nilai rata-rata & $\mathbf{9 6}$ & & Sangat terampil \\
\hline
\end{tabular}

Berdasarkan tabel diatas dapat diketahui bahwa jumlah siswa yang memperoleh kategori sangat terampil ada $123(89.78 \%)$ siswa , sedangkan kategori terampil ada $8(5.84 \%)$ siswa, kategori cukup terampil ada $3(2.19 \%)$ dan kategori cukup terampil ada 3 (2.19\%). Pada aspek tema keterampilan menulis siswa sudah sangat baik karena rata-rata puisi yang ditulis siswa sudah sesuai dengan karakteristik puisi anak dan tema. Tema yang digunakan adalah hal-hal yang sangat dekat dengan siswa seperti lingkungan, orang tua maupun binatang peliharaan. 


\section{b. Indikator Imajinasi}

Aspek imajinasi dalam kemampuan menulis puisi anak berarti kemampuan siswa terhadap penyusunan kata-kata yang tepat dan selaras dengan tema. Menurut salam dalam (Dibia,
2018) Pengimajinasian adalah susuna kata yang dapat menimbulkan imajinasi dengan adanya imajinasi seolah-olah merasa, mendengar, atau melihat sesuatu yang diungkapkan penyair.

Tabel 3. Rekapitulasi Keterampilan Menulis Puisi Anak Pada Aspek Imajinasi

\begin{tabular}{cccc}
\hline Interval & Jumlah siswa & $\mathbf{\%}$ & Kategori \\
\hline $86-100$ & 0 & $0 \%$ & Sangat Terampil \\
$76-85$ & 5 & $3.65 \%$ & Terampil \\
$56-75$ & 39 & $28.47 \%$ & Cukup Terampil \\
$10-55$ & 93 & $67.88 \%$ & Kurang Terampil \\
\hline Jumlah $\left(\sum\right)$ & $\mathbf{1 3 7}$ & $\mathbf{1 0 0 \%}$ & \\
\hline Jumlah Nilai & $\mathbf{4 6 5 0}$ & & \\
\hline Nilai rata-rata & $\mathbf{3 4}$ & & Kurang Terampil \\
\hline
\end{tabular}

Berdasarkan tabel diatas dapat diketahui bahwa tidak ada siswa yang mendapatkan kategori terampil, pada kategori terampil ada 5 (3.65\%) siswa, sedangkan kategori cukup terampil ada 39 (28.47\%) siswa dan kategori kurang terampil ada $93(67.88 \%)$ siswa. Pada aspek imajinasi keterampilan menulis siswa mendapatkan kategori kurang terampil.

\section{c. Indikator Diksi}

Aspek diksi dalam keterampilan menulis puisi berarti bagaimana siswa dalam menggunakan kata yang tepat ketika menulis menurut (Sulkifli, 2016) diksi merupakan kata indah diksi tidak hanya ada dalam puisi. Artinya, agar puisimemiliki kesan indah, kata-kata dalam puisi harus dipilih secara cermat karena puisi merupakan pemadatan kata. Jadi, kata-kata yang dipilih harus benar-benar mewakili nilai sebuah keindahan.

Tabel 4. Rekapitulasi keterampilan menulis puisi anak pada aspek diksi

\begin{tabular}{cccc}
\hline Interval & Jumlah siswa & \% & Kategori \\
\hline $86-100$ & 58 & $42.34 \%$ & Sangat Terampil \\
$76-85$ & 32 & $23.36 \%$ & Terampil \\
$56-75$ & 26 & $18.98 \%$ & Cukup Terampil \\
$10-55$ & 21 & $15.32 \%$ & Kurang Terampil \\
\hline Jumlah $\left(\sum\right)$ & $\mathbf{1 3 7}$ & $\mathbf{1 0 0 \%}$ & \\
\hline Jumlah Nilai & $\mathbf{1 0 . 0 2 5}$ & & \multirow{2}{*}{ Cukup Terampil } \\
\hline Nilai rata-rata & $\mathbf{7 3}$ & & \\
\hline
\end{tabular}

Berdasarkan aspek diatas dapat diketahui bahwa jumlah siswa yang memperoleh kategori sangat terampil ada $58(42.34 \%)$, sedangkan kategori terampil ada $32(23.36 \%)$, siswa kategori cukup terampil ada $26(18.98 \%)$ siswa, dan kategori kurang terampil ada $21(15.32 \%)$. Pada aspek diksi ketarmpilan menulis puisi anak mendapatkan kategori cukup terampil.

\section{d. Indikator Permajasan}

Aspek permajasan dalam keterampilan menulis puisi berarti cara siswa menlis puisi dengan keindahan bahasa tersendiri adalah 
Menurut tarigan dalam (Sebayang, 2018) majas adalah bahasa kiasan yang dapat menghidupakan efek dan menimbulkan konotasi tertentu.

Tabel 5. Rekapitulasi Keterampilan Menulis Puisi Anak Pada Aspek Permajasan

\begin{tabular}{cccc}
\hline Interval & Jumlah siswa & \% & Kategori \\
\hline $86-100$ & 9 & $6.57 \%$ & Sangat Terampil \\
$76-85$ & 27 & $19.71 \%$ & Terampil \\
$56-75$ & 74 & $54.01 \%$ & Cukup Terampil \\
$10-55$ & 27 & $19.71 \%$ & Kurang Terampil \\
\hline Jumlah $\left(\sum\right)$ & $\mathbf{1 3 7}$ & $\mathbf{1 0 0 \%}$ & \\
\hline Jumlah Nilai & $\mathbf{7 . 3 0 0}$ & & \\
\cline { 1 - 3 } Nilai rata-rata & $\mathbf{5 3}$ & & \\
\end{tabular}

Berdasarkan tabel diatas dapat diketahui bahwa jumlah siswa yang mendapatkan kategori sangat terampil ada $9(6.75 \%)$ siswa, sedangkan kategori terampil ada $27(19.71 \%)$ siswa, kategori cukup terampil ada $74(54.01 \%)$ siswa dan kategori kurang ada $27(19.71 \%)$ siswa. Pada aspek permajasan mendapatkan kategori kurang terampil.

Tabel 6. Rekapitulasi keterampilan menulis puisi anak pada siswa kelas V SDN 181 Pekanbaru

\begin{tabular}{cccc}
\hline Interval & Jumlah siswa & \% & Kategori \\
\hline $86-100$ & 5 & $3.65 \%$ & Sangat Terampil \\
$76-85$ & 9 & $6.57 \%$ & Terampil \\
$56-75$ & 103 & $75.18 \%$ & Cukup Terampil \\
$10-55$ & 20 & $14.60 \%$ & Kurang Terampil \\
\hline Jumlah $\left(\sum\right)$ & $\mathbf{1 3 7}$ & $\%$ & \\
\hline Jumlah Nilai & $\mathbf{8 8 1 8}$ & & \multirow{2}{*}{ Cukup Terampil } \\
\hline Nilai rata-rata & $\mathbf{6 4}$ & &
\end{tabular}

Berdasarkan tabel diatas dapat diketahui bahwa keterampilan menulis puisi anak yang berkategori sangat terampil ada 5 (3.67\%), kemudian 9 (6.57\%) berkategori terampil, dan 103 $(75.18 \%)$ berkategori cukup terampil, sedangkan siswa yang berkategori kurang terampil 20 $(14.60 \%)$ secara keseluruhan keterampilan menulis puisi anak pada siswa kelas V SDN 181 Pekanbaru memperoleh rata-rata nilai 64 berkategoti cukup terampil.

\section{Pembahasan Hasil Penelitian}

Menulis adalah suatu kegiatan menyusun dan mengorganisasikan buah pikiran menggunakan kalimat terpadu dalam bahasa tulis (Jaya, 2013). Menulis adalah aktivitas mengunggkapkan gagasan pikiran melalui media bahasa (Prayitno, 2013) Puisi anak mempunyai karakteristik bahasa yang sederhana baik dalam hal pemilihan kata maupun jangkauan penggunaan bahasa terutama yang bermain dalam wilayah bahasa kias. Aspek tema dalam keterampilan menulis puisi anak berarti keterampilan siswa dalam menuangkan ide gagasand dan pengalaman kedalam sebuah puisi. Menurut Salam dalam (Dibia, 2018) citraan atau pengimajinasian adalah gambaran dalam pikiran citraan tersebut antara lain adalah citraan penglihatan, pendengaran, perabaan, penciuman dan gerak.

Aspek imajinasi dalam keterampilan menulis puisi anak berarti keterampilan siswa dalam menggunakan kalimat yang dapat melibatkan panca indra. Menurut salam dalam (Dibia, 2018) citraan atau pengimajinasian adalah 
gambaran dalam pikiran citraan tersebut antara lain adalah citraan penglihatan, pendengaran, perabaan, penciuman dan gerak.

Aspek diksi dalam keterampilan menulis puisi anak adalah bagaimana anak dapat menuliskan kata-kata yang baik yang dapat dimengerti agar tujuan yang ingin disampaikan dapat terealisasikan. Menurut (Nurgiyantoro, 2016) bahwa pemilihan kata yaitu diksi harus dilakukan dengan intens, sehingga menghasilkan kata-kata yang terpilih berdasarkan ketepatan bunyi, bentuk, makna dan juga mungkin nilai sosialnya.

Aspek majasa pada keterampilan menulis puisi anak adalah bagaimana anak dapat menuliskan kata kata yang menari yang menjadikan puisi lebih hidup. Menurut (Pradopo, 2009) majas menyebabkan sajak menjadi menarik perhatian, menimbulkan kesegaran, hidup, dan terutama menimbulkan kejelasan gambaran dan makna.

Dari langkah-langkah analisa data yang telah dilakukan melalui penelitian ini dapat memberikan gambaran mengenai keterampilan menulis puisi anak. Berdasarkan hasil analisis diatas dapat diketahui bahwa keterampilan siswa dalam menulis puisi yang belum dikuasai adalah aspek imajinasi dan permajasan pada aspek imajinasi memang menurut (Nurgiyantoro, 2016) pada dasarnya puisi dewasa dengan puisi anak tidak jauh berbeda hanya saja puisi anak lebih terbatas baik itu dalam jangkauan imajinasi dan pemaknaannya. Jadi masih banyak siswa yang belum komplek dalam aspek imajinasi namun ada juga siswa mampu dengan menggunakan bahasa yang sederhana begitu pula dengan aspek majas dari aspek tersebut masih banyak siswa yang belum menggunakan majas secara kompleks dalam puisinya, tetapi ada juga siswa yang sudah mampu walaupun majas puisi anak tersebut masih terlihat sederhana sesuai pandangan dan kacamata anak.

Keterampilan menulis puisi berdasarkan hasil analisis dapat diketahui bahwa keterampilan menulis puisi anak yang berkategori sangat terampil ada $5(3.67 \%)$, kemudian $9(6.57 \%)$ berkategori terampil, dan $103 \quad(75.18 \%)$ berkategori cukup terampil, sedangkan siswa yang berkategori kurang terampil $20(14.60 \%)$ secara keseluruhan keterampilan menulis puisi anak pada siswa kelas V SDN 181 Pekanbaru memperoleh rata-rata nilai 64 berkategoti cukup terampil.

\section{SIMPULAN DAN REKOMENDASI}

1. Pada aspek tema siswa yang memperoleh kategori sangat terampil ada $123 \quad(89.78 \%)$ siswa, sedangkan kategori terampil ada 8 $(5.84 \%)$ siswa, kategori cukup terampil ada 3 $(2.19 \%)$ dan kategori cukup terampil ada 3 $(2.19 \%)$. Secara keseluruhan pada aspek tema mendapatkan kategori sangat terampil dengan rata-rata nilai 96 .

2. Pada aspek imajinasi siswa yang mendapatkan kategori terampil, pada kategori terampil ada 5 (3.65\%) siswa, sedangkan kategori cukup terampil ada $39(28.47 \%)$ siswa dan kategori kurang terampil ada 93 (67.88\%) siswa. Pada aspek imajinasi keterampilan menulis siswa mendapatkan kategori kurang terampil

3. Pada aspek diksi dapat diketahui bahwa jumlah siswa yang memperoleh kategori sangat terampil ada $58(42.34 \%)$, sedangkan kategori terampil ada $32(23.36 \%)$, siswa kategori cukup terampil ada $26(18.98 \%)$ siswa, dan kategori kurang terampil ada $21(15.32 \%)$. Pada aspek diksi ketarmpilan menulis puisi anak mendapatkan kateori cukup

4. Pada aspek majas jumlah siswa yang mendapatkan kategori sangat terampil ada $9(6.75 \%)$ siswa, sedangkan kategori terampil ada 27 (19.71\%) siswa, kategori cukup terampil ada $74(54.01 \%)$ siswa dan kategori kurang ada 27 (19.71\%) siswa. Pada aspek permajasan mendapatkan kategori kurang terampil.

5. Secara keseluruhan keterampilan menulis puisi anak yang berkategori sangat terampil ada 5 $(3.67 \%)$, kemudian $9(6.57 \%)$ berkategori terampil, dan 103 (75.18\%) berkategori cukup terampil, sedangkan siswa yang berkategori kurang terampil $20 \quad(14.60 \%)$ secara keseluruhan keterampilan menulis puisi anak 
pada siswa kelas V SDN 181 Pekanbaru memperoleh rata-rata nilai 64 berkategori cukup terampil.

Berdasarkan hasil penelitian yang dilakukan, berikut peneliti menyampaikan beberapa saran yang berkaitan dengan penelitian ini.

1. Aspek keterampilan yang kurang dikuasai seperti aspek imajinasi dan permajsan. Kurangnya pemahaman siswa terhadap beberapa aspek menulis puisi sehingga terjadinya kesulitan dalam proses menulis puisi. Oleh karena itu guru diharapkan untuk membimbing siswa dalam melaksanakan pembelajaran puisi dengan memperhatikan aspek-aspek menulis puisi.

2. Siswa diharapkan lebih memperhatikan materi pembelajaran menulis puisi yang diberikan guru.

3. Guru diharapkan memberikan bimbingan kepada siswa dan selalu terbuka dalam memberikan penilaian.

4. Keterampilan menulis puisi merupakan kemampuan yang pemerolehannya memerlukan pelatihan yang intensif dan selalu menamkan sikap percaya diri dengan memberikan motivasi

\section{DAFTAR PUSTAKA}

Alexander, J. (2013). Statistik Pendidikan. Pekanbaru: FKIP Universitas Riau.

Dibia, I. K. (2018). Apresiasi bahasa dan sastra indonesiaDibia, I. K. (2018). Apresiasi bahasa dan sastra indonesia. Depok: PT. Raja Grafindo Persada.

Jaya, S. (2013). Peningkatan Keterampilan Menulis Puisi Melalui Media Gambar. Jurnal Bahasa, Sastra dan Pembelajaran 1(2)

(online) http://ejournal.unp.ac.id/index.php/bsp/arti cle/download/5000/3952 (diakses $14 \mathrm{Mei}$ 2019), 87.

Lestari, H. A. (2014). Analisis Kemampuan Menulis Puisi Anak Pada Siswa Kelas V SDN 20 Kota Bengkulu. SKRIPSI, FKIP PGSD
https://eprints.uny.ac.id/25268/1/Ecy\%20

Mahardiyan\%20S\%2008201241004.pdf.

Nurgiyantoro, B. (2010). Penilaian Pembelajaran Bahasa. Yogyakarta: BPFE.

Nurgiyantoro, B. (2016). Sastra Anak (Pengantar Dunia Anak). Yogyakarta: Gadjah Mada University Press.

Pradopo, R. D. (2009). Pengkajian Puisi. Yogyakarta : Gadja Mada Universitas Press.

Prayitno, H. W. (2013). Peningkatan Keterampilan Menulis Puisi Menggunakan Teknik Inkuiri. Jurnal Bahasa dan Sastra, 2(2) (online)

https://journal.unnes.ac.id/sju/index.php/jp bsi/article/view/2399 ( diakses 14 Mei 2019), 2.

Retti, S. (2013). Peningkatan Keterampilan Menulis Puisi Malalui Prinsip-Prinsip Sugestologi Siswa Kelas Vii.1 Smp N 4 Vii Koto Sungai Sarik Kabupaten Padang Pariaman. Jurnal Bahasa, Sastra dan Pembelajaran Volume 1 Nomor 2.

Sebayang, S. K. (2018). Analisis struktur Bathin puisi Sesamar Kasih Pencari Rezeki karya Dwi Utami Nasution. Jurnal Bahasa dan Sastra Unimed https://jurnal.unimed.ac.id/2012/index.php /basastra/article/view/9318 .

Sulkifli. (2016). Kemampuan Menulis Puisi Siswa Kelas Viii Smp Negeri Satu Atap 3 Langgikima Kabupaten Konawe Utara. Jurnal Bastra, Vol. 1, No. 1.

Tarigan, H. G. (2008). Menulis Sebagai Suatu Keterampilan Berbahasa. Bandung: Angkasa. 